Research Article

Febrian Isharyadi* and E. Kristiningrum

\title{
Profile of system and product certification as quality infrastructure in Indonesia
}

https://doi.org/10.1515/eng-2021-0054

Received Sep 25, 2020; accepted Jan 13, 2021

\begin{abstract}
Quality is a universal standard that is expected by consumers of a product or service used. Consumers in general cannot individually assess this quality, with the help of an independent third party it can be done. The certification body is one element in the quality infrastructure that plays a role in providing quality assurance of products and services according to applicable standards. There are various certification bodies in Indonesia both for system and product certification, the kinds additionally range in accordance to the scope of certification. However, it is not yet known generally the condition of the system and product certification in Indonesia. The aim of this study is to conduct profiling and analyse the condition of the system and product certification in Indonesia using a comprehensive tool in order to assess part of the quality of a country's infrastructure. The results showed that there were several elements that were fulfilled, especially in terms of legality and national recognition. However, some elements still need improvement so that the certification body can do its part to ensure the quality of products and services.
\end{abstract}

\section{Introduction}

Quality is one of the criteria that concerns by consumers to consume a product or service besides price. Even though, many consumers use price as indicator the quality of a product [1]. Price and quality are become key factors for increase competitiveness of products in the market [2]. Quality is a level where a product or service is able to meet a predetermined requirement [3]. these requirements can be in the form of standards or other specifications that have been agreed upon and recognized. Quality is also defined

\footnotetext{
^Corresponding Author: Febrian Isharyadi: Center of Research and Human Resource Development, National Standardization Agency of Indonesia; Email: febrian.isharyadi@gmail.com E. Kristiningrum: Center of Research and Human Resource Development, National Standardization Agency of Indonesia
}

as the capacity of a product or service capable of meeting the needs of consumers as end users [4]. Quality is a universal language in which consumers judge a product or service. Quality products and services will provide satisfaction for customers, so they can encourage consumers to pay for a product or service [5]. For producers, quality will give added value and also enhance reputation [6]. So, the manufacturer will definitely be claimed that the products being sold are of high quality. But for consumers in general, quality cannot be assessed before a product or service is consumed [5].

In the market, quality of a product is very uncertain if no one gives a guarantee. Guarantee the quality of a product or service can be given with certification mechanism, with formal proof in the form of a certificate. Certification is mechanism that can reduce information asymmetries between producers, customer and other interested parties [2, 7-9]. Certification carried out by a credible thirdparty institution that called certification body $[4-6,10,11]$ The certification body is an independent institution that provides an assessment of a product or service that has met the specified requirements. In addition, the quality of the product produced will occur on an ongoing basis. This will make it easy for consumers to decide to consume a product or service. In addition to providing convenience for consumers, the certification is also able to have an impact on product or service penetration in the market. In fact, certification is able to provide more value, especially for products or services [12]. The certification body is one element in the quality infrastructure that plays a role in providing quality assurance of products and services according to applicable standards.

Specifically, in Indonesia, the variety types of products and services on the market provides opportunities for certification bodies to provide the services needed according to their scope. There are a number of certification bodies including product and system certification with their respective scopes. Data from the National Accreditation Committee of Indonesia (KAN) shows that in 2019 there were 261 certification bodies (systems and products) that provide services to more than 10.000 organization. This number shows that the need for system and product certifi-

๑ Open Access. ( 2021 F. Isharyadi and E. Kristiningrum, published by De Gruyter. 


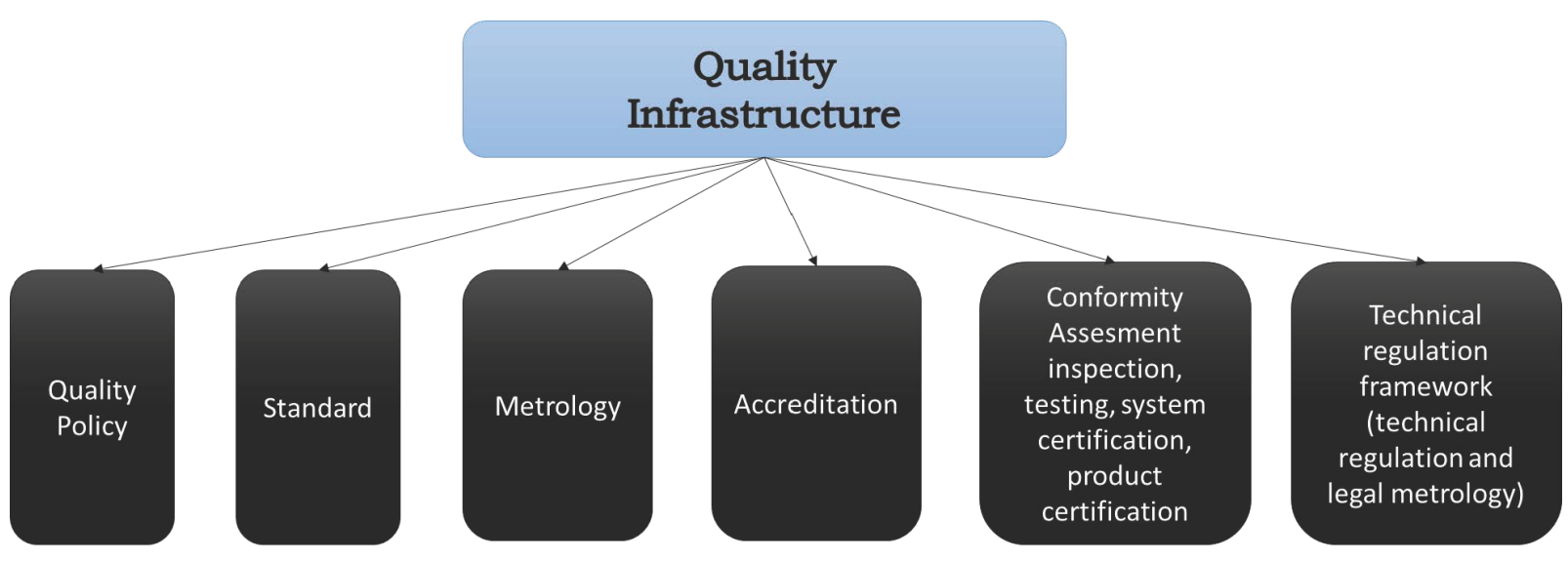

Figure 1: Building of quality infrastructure [14]

cation in Indonesia is very abundant. As one of the pillars in quality infrastructure in Indonesia, system and product certification certainly has the expected or ideal conditions. Some countries assess the ideals of system and product certification using an assessment tool to find out whether a system has been running according to the ideal, so that the results issued are better known [13].

The condition of system and product certification in Indonesia is not yet fully known, so as its level for improvements in the future have not been predicted. Therefore, in this study aimed to profiling the condition of system and product certification in Indonesia and analyzed their ideal conditions. In this study, the assessment is carried out using a comprehensive diagnostic tool that developed by The World Bank and Physikalisch-Technische Bundesanstalt (PTB) $[14,15]$. The results of the evaluation are information on the gap between the current condition and ideal conditions, so that after a gap analysis is carried out, it can provide material for improvement for product and system certification activities that are adjusted to a country's quality policy.

\section{Literature study}

\subsection{Quality infrastructure}

Quality is a level where a product or service is able to meet a predetermined requirement [3]. Quality can also be interpreted as capacity of a product or service capable of meeting the needs of consumers as end users [4]. Achieving the quality is an outcome of manufacturing or services with integrated system of several organisational processes [10]. ISO 9000 defined that quality is a level where a product or service is able to meet a predetermined requirement [3].
Every country should have a policy in terms of quality, it will build a culture that will impact the quality of life of its citizens. In order to maintain quality in a country, a supporting infrastructure is needed which is called quality infrastructure. Quality infrastructure (QI) is a system consist of organizations (public and private) together with the policies, relevant legal and regulatory framework, and practices needed to support and enhance the quality, safety, and environmental of goods, services, and processes. QI is a basic and critical element to build a system quality in a country, there are consists of several elements including quality policy, standardization, metrology, accreditation, conformity assessment (inspection, testing, system certification, product certification), and supported by governance through mandatory standards, compulsory certification, legal inspection, and effective enforcement of technical regulation framework (technical regulation and legal metrology) [1416]. All elements in the quality infrastructure must work well together so that the quality policy will be achieved. The quality policy prepared nationally illustrates a clear framework and is supported legally and in detail by each authorized party. So that the quality policy clearly illustrated the organizational structure, responsibilities, and mechanisms that conducted between the Government and the private sector $[14,15]$.

\subsection{Certification}

Certification is a mechanism that provides formal proof that a product or service has met the requirement and performed of a standard [17]. Certification activities have a role as a guard from unsafe and non-compliant products to entering the market [16]. Certification is a credible signal of quality, as the price set by the seller contains no meaningful information absent certification. In the buyer certification case, 
certification acts as an inspection tool [11]. Certification can give to consumer a full information quality of product and improve willingness to pay for a product [9], so that certification can improve market efficiency [11]. Certification is commonly used as attempt to satisfy consumer demand and increase the evaluation of products [18]. In addition, certification can help organization to disclosure of information about the hidden attributes to suppliers, customers, and other stakeholders [19] and also involves the definition and enforcement of standards that set norms, levels and values for different aspects of the production process [20].

System and product certification are part of the element of conformity assessment in quality infrastructure. The certification activity is carried out by an independent third party, in which in the process an evaluation of a continuity of the organization, products, or services is carried out continuously and comprehensively [21]. Independent thirdparty that provides certification is called certification body. ISO Guide 65 /EN 45011 and Council Regulation (EC) No 834/2007 require certification bodies to conduct risk assessment during certification process [22]. So, it is concluded that an organization has been able to provide or produce a product or service that can be guaranteed quality and occur in a sustainable manner.

\subsubsection{System certification}

In this era system certification become something that is very important and crucial, especially for an organization. System certification used by organization almost in all sectors activity (business, manufacturer, service) either the public or private sector [17, 21]. A system certification is needed for an organization because it is able to provide several advantages including being able to increase the performance of the business [17]. System certification audited by independent third-party which ensures that the system has been appropriately implemented by an organization [21]. Independent third-party that provides system certification is called system certification body. A recognized certification body, before providing certification must first undergo an accreditation process. The accreditation process is a conformity assessment process carried out by an accrediting body of a certification body in conducting certification activities. The assessment is carried out in accordance with operational standards and applicable regulations. In the operational system and product certification there are fundamental differences in the standard procedures used. For system certification, the certification body conducting certification must be accredited according to the standard ISO/IEC 17021-1:2015 - Conformity assessment - Requirements for bodies providing audit and certification of management systems - Part 1: Requirements. ISO 17021 is an International Standard that provides Certification Bodies (CB) with a set of requirements that will enable them to ensure that their management system certification process is carried out in a competent, consistent and impartial manner [37].

System certification which is generally known is divided into two, first namely international system certification among them ISO 9001 (Quality Management System (QMS)), ISO 14001 (Environmental Management System (EMS)), ISO 22000 (Food Safety Management System (FSMS)), Hazard analysis and critical control point (HACCP),

Table 1: Number of valid certificate and site number of certification system standards (2018-2019)

\begin{tabular}{ccccc}
\hline \multirow{2}{*}{ Certification System Standard } & \multicolumn{2}{c}{ Total valid certificates } & \multicolumn{2}{c}{ Total number of sites } \\
\cline { 2 - 5 } & 2018 & 2019 & 2018 & 2019 \\
\hline ISO 9001 & 878.664 & 883.521 & 1.180 .965 & 1.217 .972 \\
ISO 14001 & 307.059 & 312.580 & 447.547 & 487.950 \\
ISO/IEC 27001 & 31.910 & 36.362 & 59.934 & 68.930 \\
ISO 22000 & 32.120 & 33.502 & 36.105 & 39.651 \\
ISO 45001 & 11.952 & 38.654 & 14.607 & 62.889 \\
ISO 13485 & 19.472 & 23.045 & 24.123 & 31.508 \\
ISO 50001 & 18.059 & 18.227 & 46.770 & 42.215 \\
ISO 22301 & 1.506 & 1.693 & 5.282 & 6.231 \\
ISO 20000-1 & 5.327 & 6.047 & 7.291 & 7.778 \\
ISO 28000 & 617 & 1.874 & 666 & 2.403 \\
ISO 37001 & 389 & 872 & 1.541 & 4.096 \\
ISO 39001 & 547 & 864 & 1.422 & 1.852 \\
\hline Total & 1.307 .622 & 1.357 .241 & 1.826 .253 & 1.973 .475 \\
\hline
\end{tabular}


ISO 50001 (Energy Management System), ISO 27001 (information security), ISO 45001 (Occupational Health And Safety Management Systems (OHSMS)), ISO 13485 (Quality Management Systems for Medical Devices (MDQMS)), ISO 22301 (Social Security (SS)), ISO 28000 (Security Management System for Supply Chain (SMSSC)), ISO 37001 (Antibribery Management System), and ISO 39001 (Road Traffic Safety Management System) [21, 23]. Another one of system certification is private certification among them British Retail Council (BRC), Global good agricultural practices (GAP), Occupational Health and Safety Assessment Series (OHSAS) 18000, EU Ecolabel, Forest Stewardship Council (FSC), Marine Stewardship Council (MSC), Green Dot, etc. The growth of system certification is increasing every year, even the total valid certificates issued in the world in 2019 for all system certifications reached 1.357 .241 certificates given to 1.973.475 sites [23].

\subsubsection{Product certification}

Product quality is a characteristic that indicates the level of product goodness that has the ability to be used as desired by the consumer [24]. To guarantee the quality of product, a product certification process can be carried out. Product certification is the mechanism of certifying a product against fulfilment the specified requirements of product standard [1]. This process is an effective mechanism for assessing compliance with regulations and standards addressing safety, quality and other product characteristics. Product certification done from pre-market approval and certification is a legal requirement for manufacturers of many types of products, components and accessories to meeting mandatory certification requirements. Manufacturers may also choose to have their products tested for compliance with the technical requirements of voluntary standards [1].

Product certification is also a written guarantee mechanism from an independent third-party, the third-party states that the products and processes that support it comply the health, security, safety and environmental requirements according to predetermined standards. This certification aims to guarantee product safety, export facilitation, and facilitate industry in implementing standards. In addition, product certification has significant effect on brand trust [19, 24]. Product certification generally gives a certification mark on a certified product. Certification mark on a commercial product indicates the existence of an accepted

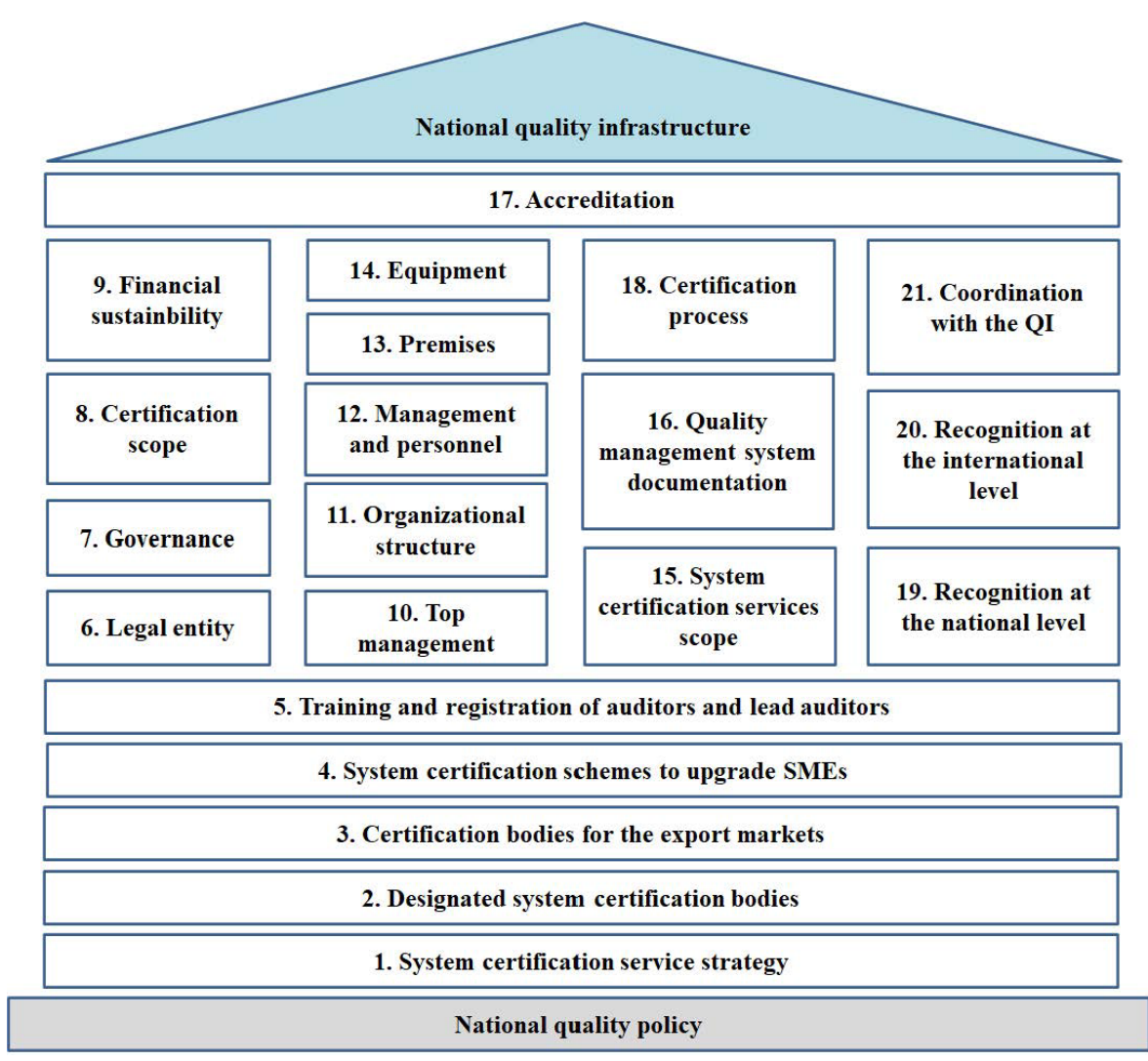

Figure 2: Overview of pillars and building blocks of system certification for national quality infrastructure [14] 


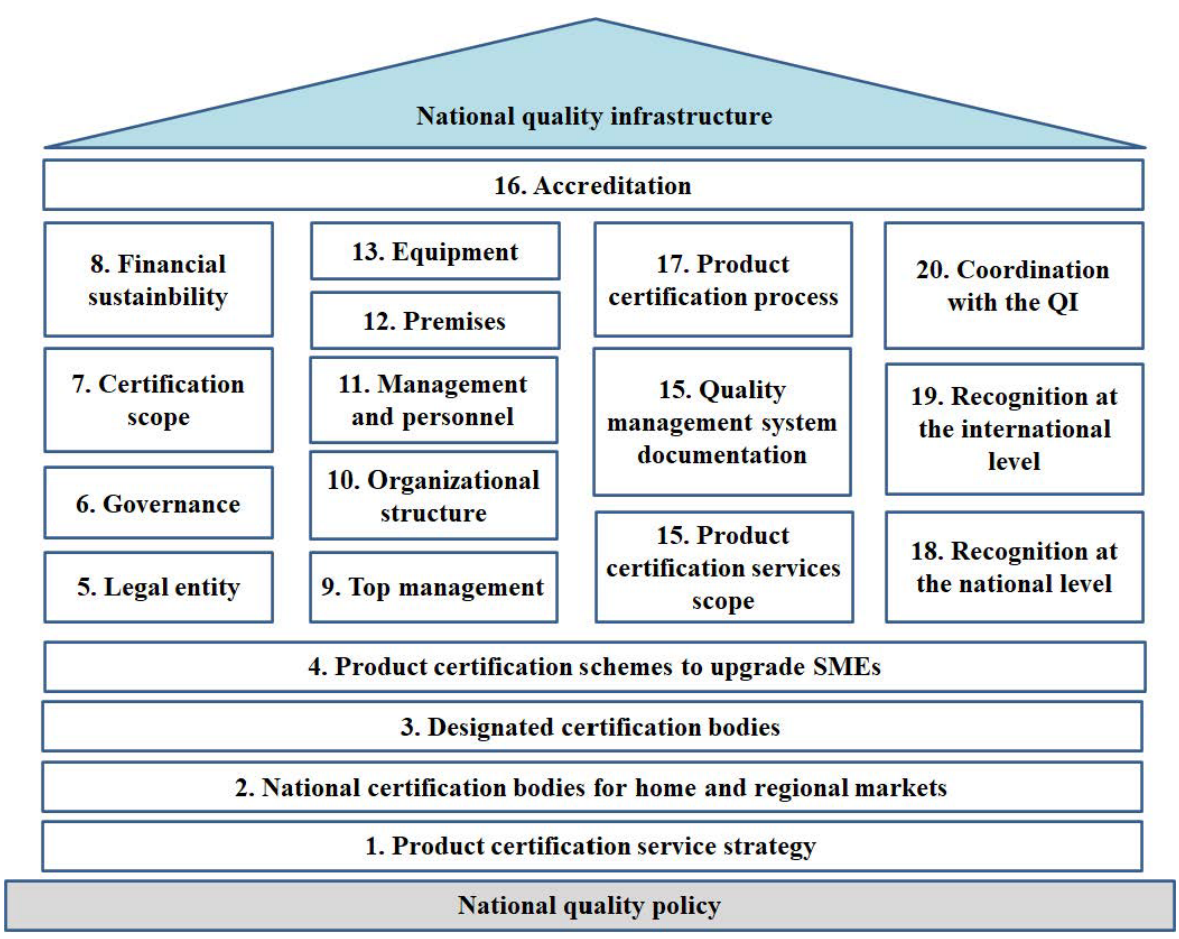

Figure 3: Overview of pillars and building blocks of product certification for national quality infrastructure [14]

product standard and a claim that the manufacturer has verified compliance with related standards [1]. Standard is technical requirements or something that is standardized, including procedures and methods that are prepared based on the agreement of all parties / governments / international decisions related to the consideration of requirements for safety, security, health, environment, scientific and technological developments, experience, and developments.

The independent third party that provides this guarantee is known as a product certification body. Product certification body is not arbitrary in carrying out the certification process. Certification bodies that carry out product certification activities, they must be accredited with ISO / IEC 17065: 2012 standards - Conformity assessment - Requirements for bodies that certify products, processes and services [26]. This International Standard contains requirements for the competence, consistent operation and impartiality of product, process and service certification bodies. Certification bodies operating to this International Standard need not offer all types of products, processes and services certification. Certification of products, processes and services is a third-party conformity assessment activity [38]. Specifically, for product certification, according to ISO 17067 there are several types of schemes in product certification [39] (Table 2).
Table 2: Certification product scheme

\begin{tabular}{cc}
\hline Scheme & Information \\
\hline 1a and 1b & Batch inspection \\
2 & Testing through market supervision \\
3 & Product testing at the factory \\
4 & Type testing and production control \\
5 & Type testing and quality control, including \\
& market supervision \\
\hline
\end{tabular}

The difference between system certification (Figure 2) and products (Figure 3 ) is seen in the pillars and building blocks that support the national quality infrastructure with the quality policy remaining as its main foundation [14]. Pillars and building blocks are elements that can be used in evaluating the ideals of a process, in this case system certification and product certification. Based on the characteristics, the ideal level of system and product certification services in a country is determined on infrastructure, recognition, establishment, services, human resources, and demand orientation. Ideal level is divided into 4 categories starting from the limited level, basic, advanced, to ideal. 


\subsection{Benefit of certification}

The benefits of system certification are felt by consumers as convenience in determining the products and services to be consumed. With proof of certification that is generally listed on the label, consumers' decisions become faster in choosing a product or service. In addition to providing benefits for consumers, the benefits of certification are also felt by producers both internally and externally [10, 21, 2736] (Table 3). With the benefits felt by both producers and consumers should be able to improve the performance of the existing quality infrastructure. Benefits that are felt not only by big organizations or companies but also by small and medium enterprises (SMEs) [25, 33, 41, 47, 58].

Table 3: Benefits of system and product certification

\begin{tabular}{|c|c|c|}
\hline No & Benefit & Reference \\
\hline 1 & Access to new markets & {$[21,29,32,33,41,58]$} \\
\hline 2 & Corporate image improvement & {$[10,21,29,32-34,41]$} \\
\hline 3 & Market share improvement & {$[27-29,31,32,36,41,58]$} \\
\hline 4 & As a marketing tool & {$[29,58]$} \\
\hline 5 & Customer relationship improvements & {$[29,31,32,34,41]$} \\
\hline 6 & Customer satisfaction & $\begin{array}{c}{[10,21,27,29,32,36,41,} \\
58]\end{array}$ \\
\hline 7 & Customer communication improvements & {$[29,41]$} \\
\hline 8 & Productivity improvements & {$[21,29,31-35,41]$} \\
\hline 9 & Product quality improvement & {$[21,29,32,41,58]$} \\
\hline 10 & Product defect rate decreases & {$[29,32,36,41,58]$} \\
\hline 11 & Quality awareness improvements & {$[21,29,33]$} \\
\hline 12 & Definition of the personnel responsibilities and obligations & {$[29,32,58]$} \\
\hline 13 & Delivery time improvements & {$[21,29,32,41,58]$} \\
\hline 14 & Internal organization improvements & {$[21,27,29]$} \\
\hline 15 & Non-conformities decrease & {$[29,32,36,41,58]$} \\
\hline 16 & Customer complaints decrease & {$[29,32,36,41]$} \\
\hline 17 & Competitive advantage improvement & {$[10,21,29,32,34,41,58]$} \\
\hline 18 & Internal communication improvements & {$[29,34,35,47]$} \\
\hline 19 & Personnel motivation & {$[28,29,32-34,41,58]$} \\
\hline 20 & Enhancing innovation & {$[30,41]$} \\
\hline 21 & Increase organization performance & {$[10,31]$} \\
\hline 22 & Increase financial outcomes & {$[10,21,31,32,34,41,58]$} \\
\hline 23 & Facilitate the access to governmental incentives & {$[21]$} \\
\hline 24 & Cost reduction & {$[21,28,32,41,58]$} \\
\hline 25 & Waste reduction & {$[35,41,58]$} \\
\hline 26 & Process improvements & {$[21,30,34]$} \\
\hline 27 & System documentation improvements & {$[21,32,34,36,58]$} \\
\hline 28 & Increase quality performance & {$[31,36]$} \\
\hline 29 & Export improvements & [32] \\
\hline 30 & Approach for risk management in business & {$[34,47]$} \\
\hline 31 & $\begin{array}{l}\text { Provide better alignment of strategic, tactical, and operational policies and } \\
\text { objectives }\end{array}$ & [34] \\
\hline 32 & Better decision-making & [34] \\
\hline 33 & Improve the compliance of legislation & {$[34,47]$} \\
\hline 34 & Improvement of problem solving & [35] \\
\hline
\end{tabular}


Table 4: Score categories of comprehensive diagnostic condition of quality infrastructure [15]

\begin{tabular}{|c|c|}
\hline Score & Categories \\
\hline $0.0-1.0$ & $\begin{array}{l}\text { Little or nothing is in place, and the country must develop the relevant elements of a QI ecosystem from } \\
\text { scratch }\end{array}$ \\
\hline $1.1-2.0$ & A rudimentary system needing much fundamental development is in place. \\
\hline $2.1-3.0$ & A reasonable system is in place but needs further development \\
\hline $3.1-4.0$ & A good system is in place with no need for fundamental development, but maintenance is important \\
\hline
\end{tabular}

\section{Method}

This research divided into two stages. First, identification the profile of system and product certification in Indonesia. In this stage, we are using descriptive quantitative method to describe current condition of system and product certification in Indonesia. The conditions described include activities from product and system certification activities using the number of certification approaches that have been carried out using data from KAN, the national accreditation body in Indonesia in 2019.

The second stage is identification and evaluate the level of system and product certification in Indonesia using comprehensive tools for assessing a country's quality infrastructure (QI) based on the detailed description of the Ensuring Quality [14]. This tool designed and developed by The World Bank Group and the Physikalisch-Technische Bundesanstalt, the National Metrology Institute of Germany [14] in order to help development partners, researcher, and governments to assess and analyse a country's QI ecosystem [15]. The Comprehensive Diagnostic Tool follows a specific logic, starting from the policy and legal environment before dealing with each of the QI elements. The outcome provides qualitative results that an expert can turn into quantitative results [15]. The result can be used as recommendations for how to bridge the gaps of current and ideal condition of QI in a country, support reform, and also to build institutional capacities. Quality infrastructure which is the scope of the research is the current condition of the system certification and product certification in Indonesia based on the assessment of experts. The experts give comprehensive diagnostic current condition of the system and product certification in Indonesia based on the concept of building blocks arranged in four pillars to describe a specific QI service, there are (1) legal and institutional framework, (2) administration and infrastructure, (3) service delivery and technical competency, and (4) external relations and recognition. The expert giving the assessment is an assessor from the KAN who has expertise in determining the conditions of the system certification bodies and product certification bodies. The scale of level is 1-4 (Table 4). The results of the assessment are displayed in graphical radar diagram for showing the conditions of the system certification body and the product certification body so that it can be identified which parts of the certification pillar need improvement.

\section{Result and discussion}

\subsection{Condition of system certification}

Based on the results of the study, as data in the year of 2019 shows that total number of system certification bodies in Indonesia reached 136 certification bodies with a total of 7196 clients. The number of certification bodies which is conveyed in this study are accredited by KAN. If we discuss the system certification and product certification in Indonesia, it will not be separated from KAN as the national accreditation body owned by the Indonesian country. KAN accredited operational and performance for system certification bodies and product certification bodies. KAN has also been recognized internationally through the International Accreditation Forum (IAF) in the main scope of Product Certification - ISO / IEC 17065, Management Systems Certification - ISO / IEC 17021-1, and Certification of Persons - ISO / IEC 17024 and its derivative scopes including for ISO 22000 (FSMS), ISO 9001 (QMS), ISO 14001 (EMS), ISO / IEC 27001 (ISMS) and ISO 50001 (EnMS) [62].

The number of certification bodies that exist their clients shows a balanced value. However, if seen based on the type of certification there are several things that need attention. In Figure 4, it can be seen that the dominant certification of quality management system is the most popular system certification compared to several others. This indicates that the company or organization at this time has begun pay attention to how a business can take place continuously well and sustainably. The implementation of quality management system certification is able to have a good impact on the activities of a business or organization both internally and externally. ISO 9001 certification or often called Quality Management System (QMS) certification is a 


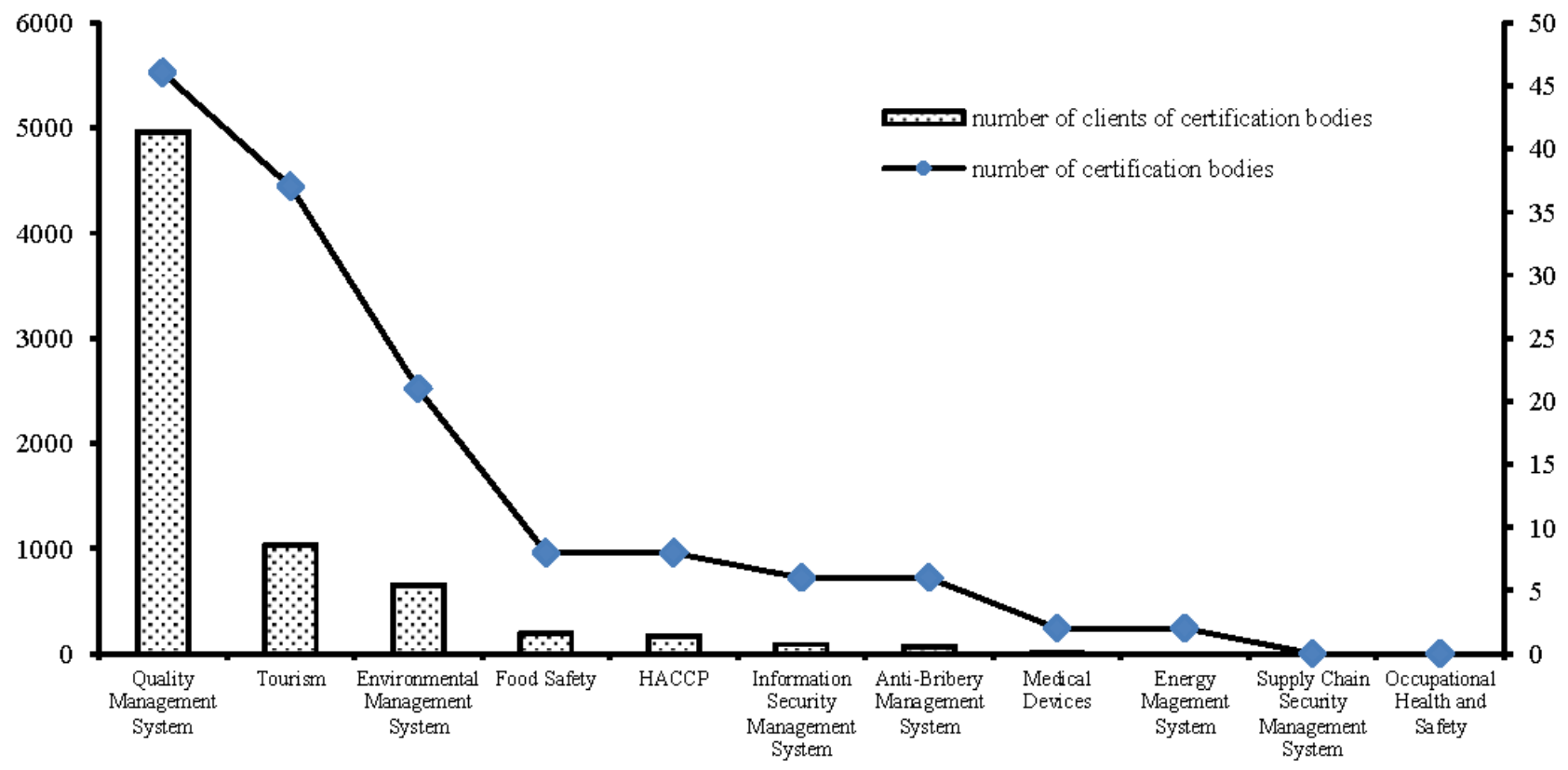

Figure 4: Profile of system certification bodies in Indonesia

voluntary. QMS published the first version of the ISO 9000 series of International Standards in 1987, as response to the growing internationalization of business and the need for common quality management system standards [40]. QMS also can be as a tool to evaluate, measure, control, and improving organization processes as they move toward realizing their goals and targets [41]. QMS based on a PDCA (Plan-Do-Check-Act) approach and quality management principles that should lead the organization to improved performance [40] with risk-based thinking [35]. Its application strongly supported by the motivation [42], policies and goals of an organization [8]. An organization to carry out QMS certification is generally driven by two factors, there are internal and external motivation $[8,21,40]$. Internal motivation is generally a company's intention to improve internal performance, efficiency in production, improvement of quality awareness, and promotion of quality and procedures to expand internationally [33]. And external motivation driven by organization purpose to access to new markets, give customer satisfaction, achieve financial outcomes, improvement of market share and elevate global recognition and reputation [10, 43].

There is also an interesting thing that system certification, especially management in the tourism sector occupies the second largest exceeds food safety certification which is a basic human need. That is because that several regulations have been issued requiring that a tourism business implement a tourism management system, so that inevitably the tourism business for the sake of its survival will imple- ment the management system. For consumers, this is a good thing, because every tourist will get a guarantee of security, comfort, and safety when conducting tourism activities. So that the purpose of tourists visiting or enjoying a tourist destination is achieved. The system certification condition also shows, for a certification system with a large number of clients facilitated by a large number of certification bodies.

Others implementation of system certification in Indonesia are EMS, FSMS, HACCP, information security management system, MDQMS, SMSSC, anti-bribery management system, energy management system, and OHSMS. The certification system has its respective functions. FSMS is a systematic procedure for the identification, evaluation and control of hazards and risks in each food process to ensure food product is safe. Food industry has a responsibility to produce safe food and reducing illness of consumer. In addition, FSMS also can give confidence for food industry to the market [2, 44-46]. EMS certification has impact for organizations to support and improve environmental performance, prevention of environmental risks, environment protection, improved company image, and efficient use of natural resources, that indicate organization compliance with legal requirements, competence and awareness, operational control and environmental performance assessment to achieve sustainable development of business strategies [48-50]. Energy management system certification has impact to consumers' willingness to pay (WTP) beyond the expected energy savings associated [7]. And OHSMS certification has impact to eliminate or min- 


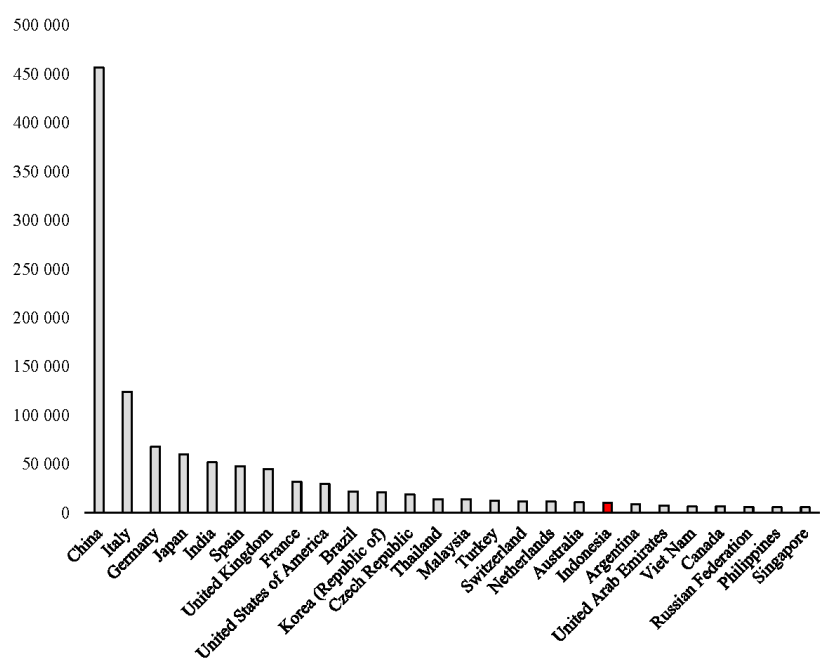

Figure 5: Comparison of the total management system certificates awarded in each country in 2019

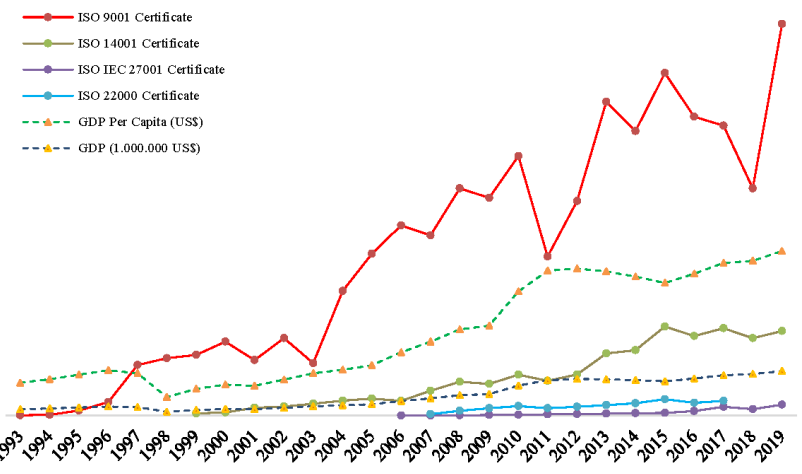

Figure 6: The growth of several certification systems compared to the value of GDP and GDP per capita in Indonesia

imise risk to employees and other interested parties who may be exposed to occupational health and safety risks associated with its activities [47].

The number of certificates that have been awarded to organizations in Indonesia is quite high. However, when compared to other countries, this number is still small, especially when compared to the number of certifications given in countries with large population sizes approaching Indonesian countries such as China and the United States (Figure 5). Even in Southeast Asia, the number of management system certificates awarded in Indonesia is still below that of neighbouring countries such as Thailand and Malaysia. This indicates that many organizations or companies not yet implemented a management system in their activities. Based on many literatures, it shows that the benefits that can be obtained in implementing the certification system are very abundant, one of which is being able to increase market share and income. With these facts the assumption is that if many organizations or companies do certification, it will have an impact on their financial condition for the better. This impact will certainly increase the value of Gross Domestic Product (GDP) and GDP per capita of a country, where both are indicators of a country's economic growth [59-61]. Therefore, we try to compare the growth of several certification systems with the growth in GDP and GDP per capita in Indonesia (Figure 6). The results show that the growth in the number of certifications each year is followed by the growth in GDP and GDP per capita. In Figure 6, it can be seen that even though there was a decrease in the number of certifications in 2011 and 2018, the GDP and GDP per capita values are still relatively stable.

\subsection{Condition of system certification}

Based on the results of the study, as data in the year of 2019 shows that total number of product certification bodies in Indonesia reaches 122 certification institutions with the number of clients reaching 7651 . Current condition of product certification can be seen in Figure 7. Product certification with the most clients are for halal products. The issuance of the halal product guarantee law with mandatory implementation in 2019, in article 4 of Law No. 33 of 2014 it states "Products that enter, circulate and are traded in the territory of Indonesia must be certified halal" [51]. Halal certification is a checked process the quality of product is complies with halal requirements [52]. As a country with the largest Muslim majority in the world, of course, halal product certification is a very important part of ensuring the halalness of the products that consumed [53]. At least encourages business actors to be able to certify their products with halal certificates. Halal certification able to provide added value, so that industry will increase the competitiveness of Indonesian products in the international world, especially for countries with Muslim dominant [54].

Certification does not guarantee market access, but it can make success more likely when market integration and linkages are established. Certification can help to establish longer-term and more direct trading relationships which can improve long-term income stability and reduce price volatility [55]. Likewise, for product certification because there are several regulations that require certain products to be entered into the market which must meet certain requirements, for example the mandatory SNI regulations. With these consequences, companies are required to certify their products in accordance with applicable rules and regulations. Specifically, for timber legality, in addition to being compulsory, timber legality certification is able to provide better acceptance especially for export markets. So as to increase competitiveness with other countries. What 


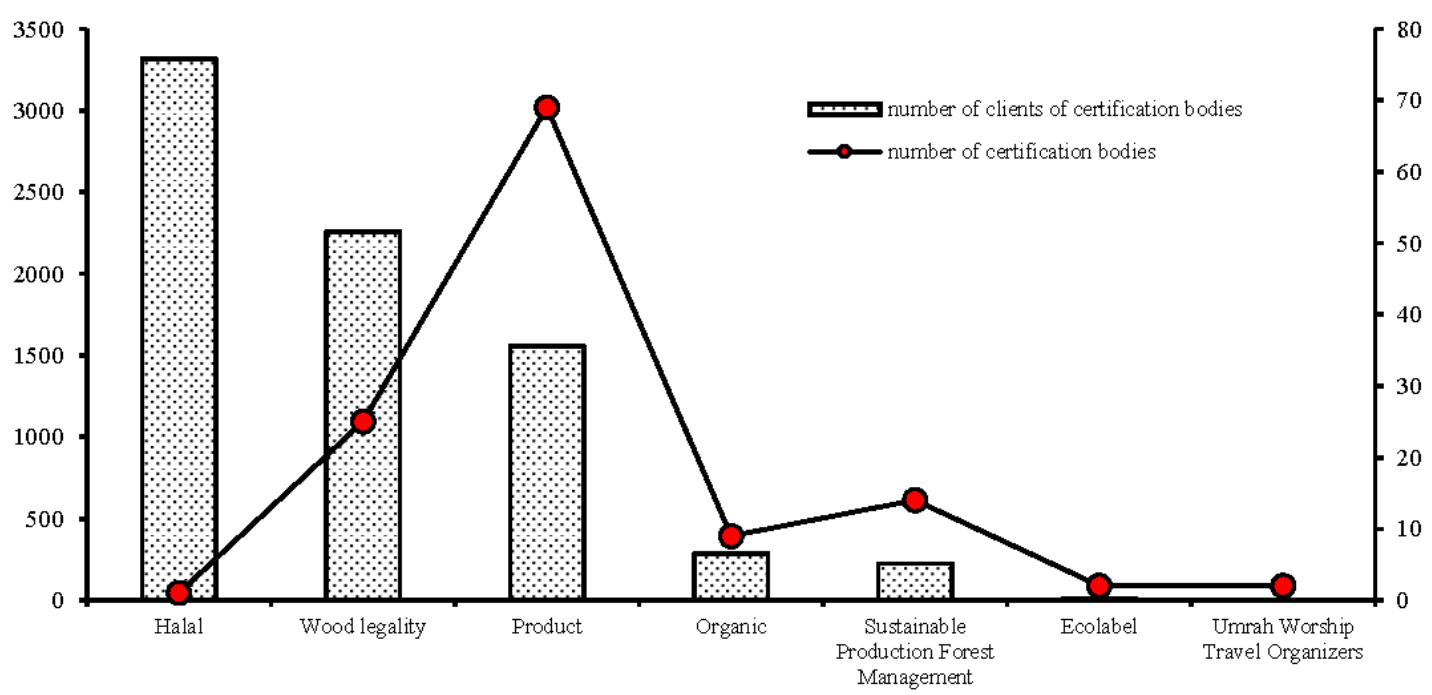

Figure 7: Profile of product certification bodies in Indonesia

is interesting in Figure 7 is that with the greatest number of clients, halal product certification is only carried out by 1 certification body that is an authority, namely BPJPH. This invites the question whether the amount is able to facilitate the needs of existing clients so as to provide maximum results.

\subsection{Comprehensive condition system and product certification as QI}

The results of the assessment ideal level of the system and product certification in Indonesia cover 4 major aspects according to the infrastructure pillars, namely (1) legal and institutional framework (sector and entity), (2) administration and infrastructure, (3) service delivery and technical competency, and (4) external relations and recognition. The level of system certification (Figure 8 ) and product certification (Figure 9) show that some elements are in ideal condition, but there are also some elements that need improvement and improvement. The element that is near to ideal condition are the system and product certification is the legal and institutional framework (sector and entity) and service delivery and technical competency. Both of these are the instruments of a certification body in carrying out certification activities both in legality and competence.

In the system certification and product certification, there are some similarities in conditions that have fulfilled the whole in terms of legal entities, designation by the designation body, national arrangements, top management, quality management systems, and recognition at the national level. The condition in Indonesia of national equip- ment that has an impact on product recognition has been very good, especially with the existence of regulations that require some products to meet standard requirements so as to provide protection for consumers.

Some elements still need improvement so that certification bodies in Indonesia can guarantee a good and comprehensive quality of products and services traded in Indonesia so as to provide an added value that will increase competitiveness. The conditions that have not been ideal in the system and product certification in Indonesia are identified almost similarly in both the elements of certification strategy, certification schemes to upgrade SMEs, financial sustainability, organizational structure, management and personnel, premises, equipment, certification scopes, accreditation, and coordination within the QI. The QI system and policy should reflect the current national and international condition, perceptiveness and predictability [16]. An assessment of the certification process shown that the certification strategy has not been well-drawn in the future. This causes the strategy of the system and product certification not yet well formed for the future, for example in the form of a roadmap. This also indirectly impacts the elements of the organizational structure that will be developed which require management, personnel, premises, and equipment as needed. Figures 8 and 9 it is also shown that as one of the building blocks of system and product certification, the certification scheme for SMEs is not yet ideal for product certification. In the system certification this is ideal because it is based on several research results that show the benefits of system certification for both big and small businesses $[41,56,57]$. 


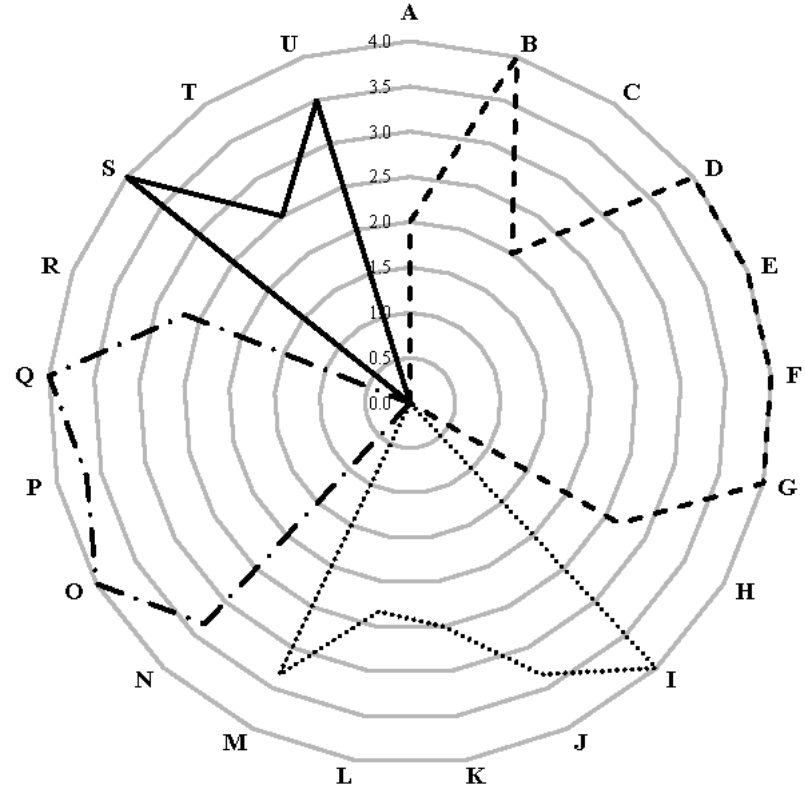

Figure 8: Radar diagram as results of the ideal level assessment for system certification in Indonesia (A) system certification strategy; (B) designated system certification bodies; (C) certification bodies for the export markets; (D) system certification schemes to upgrade SMEs; (E) training and registration of auditors and lead auditors; (F) legal entity; (G) governance; $(\mathrm{H})$ financial sustainability; (I) top management; (J) organizational structure; (K) management and personnel; (L) premises; (M) equipment; (N) system certification scopes; (O) quality management system documentation; $(\mathrm{P})$ certification process; $(\mathrm{Q})$ surveillance process; $(\mathrm{R})$ accreditation; (S) recognition at national level; $(\mathrm{T})$ recognition at international level; (U) coordination within the QI

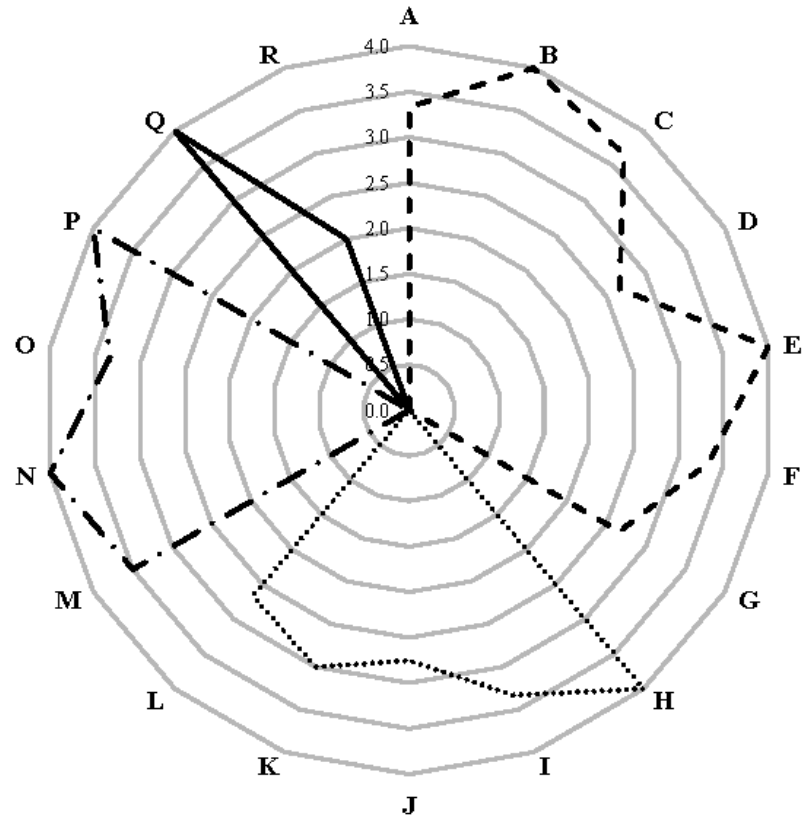

Figure 9: Radar diagram as results of the ideal level assessment for product certification in Indonesia (A) product certification strategy; (B) national certification body for the home and regional markets; (C) designated product certification bodies; (D) product certification schemes to upgrade SMEs; (E) legal entity; (F) governance; (G) financial sustainability; (H) top management; (I) organizational structure; (J) management and personnel; (K) premises; (L) equipment; (M) product certification scopes; $(\mathrm{N})$ quality management system documentation; $(0)$ accreditation; $(\mathrm{P})$ certification process; $(\mathrm{Q})$ recognition at national level; $(\mathrm{R})$ coordination within the $\mathrm{QI}$

Result measurement framework Key performance indicator

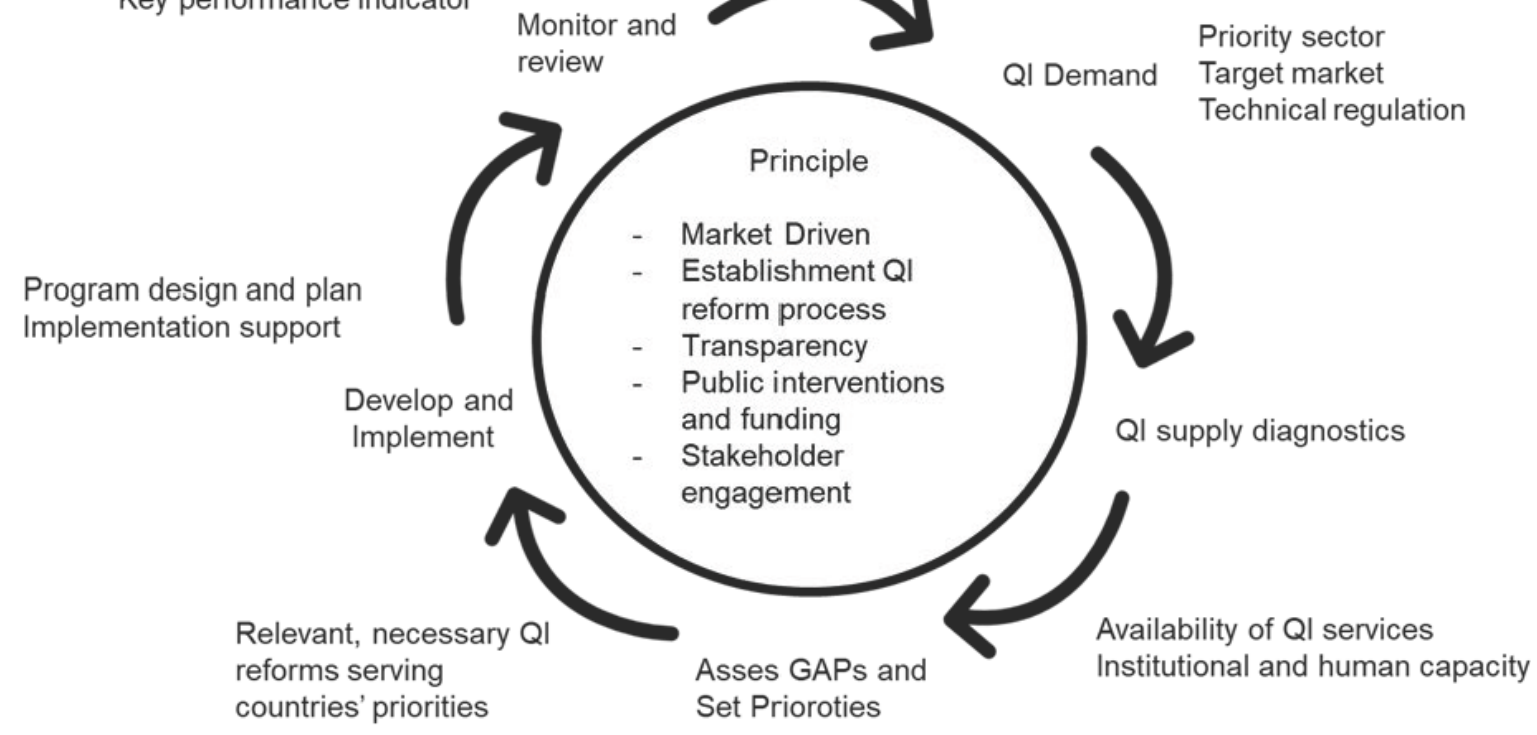

Figure 10: QI development cycle [15] 
QI development is similar to the PDCA process approach to QMS. The development process can be carried out in a cycle that is mutually sustainable (Figure 10). The initial process starting from planning with an approach to the market, stakeholders, funding, and the public will certainly produce a need for QI. This planning certainly requires support so that it can be realized in accordance with predetermined priority sectors and targets. The results of the implementation are then monitored and reviewed to obtain further developments in the future so that improvements and development to be better than the previous condition. Based on the results of the assessment of system and product certification in Indonesia, it is expected to be an ingredient and guide for stakeholders involved in making plans to make this certification process better than now. Another important thing is coordination between quality infrastructure in finding a formula that has the right policy in carrying out capabilities in accordance with their responsibilities which lead to one goal, to be able to implement a better quality of life.

\section{Conclusion}

The existing condition of system and product certification in Indonesia compared with the ideal conditions, it still needs some fundamental improvements including in terms of the certification strategy. The determination of this strategy will catalyse the improvement of the level in several other elements, so that the ideal level will be achieved. The results of this study are one of the materials that can be used in determining the certification strategy as a quality infrastructure. The limitation of this research is that it only assesses the condition of the certification system and certification products in Indonesia. There has not been a condition assessment of other QIs. For further research in order to be able to do the assessment of the ideal level of QI as a whole the quality policy, and comparing the results of the assessment with conditions from other countries to determine the position of Indonesia's QI. Further research can also be carried out to measure the level of maturity of the overall quality infrastructure in Indonesia so that quality policy can be achieved which has implications for improving the quality of life of the entire population.

Acknowledgement: The author would like to thank you to the Centre of Research and Human Resource Development, the National Standardization Agency of Indonesia for the funds provided in the implementation of this research. Our gratitude also goes to the experts who have helped fill in the questionnaire used.

Author contribution: All authors have equal contribution as main contributor to this paper.

\section{References}

[1] Likos E, Yapici F. Product Certification on Furniture Industry. In: Söğütlü C, Döngel N, Çinar H, İmirzi Ö, Yilmaz K, Öztürk Y, Akkuş $B$, editors. The XXIX ${ }^{T H}$ International Conference Research for Furniture Industry; 2019 Sep 19-20; Ankara, Turkey; 2019. p. 30913.

[2] Escanciano C, Santos-Vijande ML. Implementation of ISO-22000 in Spain: obstacles and key benefits. British Food Journal. 2014 Sep 30;116(10):1581-99. https://doi.org/10.1108/BFJ-02-20130034.

[3] International Organization for Standardization. ISO 9000:2015 Quality management systems - Fundamentals and vocabulary. Geneva: ISO; 2015.

[4] Renard MC. Quality certification, regulation and power in fair trade. Journal of rural studies. 2005 Oct 1;21(4):419-31.

[5] Dranove D, Jin GZ. Quality disclosure and certification: Theory and practice. Journal of Economic Literature. 2010 Dec;48(4):93563.

[6] Elfenbein DW, Fisman R, McManus B. Market structure, reputation, and the value of quality certification. American Economic Journal: Microeconomics. 2015 Nov;7(4):83-108.

[7] Houde S. How consumers respond to product certification and the value of energy information. The RAND Journal of Economics. 2018 Jun;49(2):453-77. doi:10.1111/1756-2171.12231.

[8] Bravi L, Murmura F, Santos G. The ISO 9001: 2015 quality management system standard: Companies' drivers, benefits and barriers to its implementation. Quality Innovation Prosperity. 2019 Jul 31;23(2):64-82.

[9] Mishra BK, Prasad A, Mahajan V. Imperfect Quality Certification in Lemons Markets. Theoretical Economics Letters. 2020 Dec 15;10(06):1260-75. https://doi.org/10.4236/tel.2020.106077.

[10] Hussain T, Eskildsen JK, Edgeman R. The intellectual structure of research in ISO 9000 standard series (1987-2015): A Bibliometric analysis. Total Quality Management \& Business Excellence. 2018 May 6; 31(11-12), 1195-224. doi: 10.1080/ 14783363.2018.1469977.

[11] Yan D, Vossler CA, Gilpatric SM. Product quality and third-party certification in potential lemons markets. The University of Tennessee, Knoxville (TN): Department of Economics, Haslam College of Business 2020 Dec. Working Paper No: \#2020-04. Protocol No. UTK IRB-19-05210-XM.

[12] Tarí JJ, Heras-Saizarbitoria I, Dick G. Internal and external drivers for quality certification in the service industry: Do they have different impacts on success?. Service Business. 2014 Jun 1:8(2): 337-54.

[13] Van Looy A, De Backer M, Poels G, Snoeck M. Choosing the right business process maturity model. Information \& Management. 2013 Nov 1;50(7):466-88.

[14] Kellermann M. Comprehensive Diagnostic Tool: Annex to the QI Toolkit. International Development in Practice. Washington DC 
(US): International Bank for Reconstruction and Development / The World Bank and Physikalisch-Technische Bundesanstalt (PTB), 2019.

[15] Kellermann M. Ensuring Quality to Gain Access to Global Markets: A Reform Toolkit. International Development in Practice. Washington DC (US): International Bank for Reconstruction and Development / The World Bank and Physikalisch-Technische Bundesanstalt (PTB), 2019. doi:10.1596/978-1-4648-1372-6.

[16] Shen J, Zhang Y, Guo B, Zheng S. Coupling Relationship Analysis between Quality Infrastructure and Ecological Environment Quality for Policy Implications. International Journal of Environmental Research and Public Health. 2020 Jan;17(20):7611. doi:10.3390/ijerph17207611.

[17] Alič M. Giving-up management system certification: A potential early warning signal?. Organizacija. 2012 Jan 4;45(2):59-74.

[18] Prell M, Zanini MT, Caldieraro F, Migueles C. Sustainability certifications and product preference. Marketing Intelligence \& Planning. 2020 Apr 9;38(7):893-906. https://doi.org/10.1108/MIP12-2019-0616.

[19] Rosiawan M, Singgih ML, Widodo E. The benefit attributes of the Indonesian National Standard (SNI) product. In SHS Web of Conferences 2018 (Vol. 49, p. 01003). EDP Sciences.

[20] Samerwong P, Bush SR, Oosterveer P. Implications of multiple national certification standards for Thai shrimp aquaculture. Aquaculture. 2018 Aug 1;493:319-27. doi: 10.1016/ j.aquaculture.2018.01.019.

[21] Fonseca L, Domingues JP, Baylina P, Calderón M. Management system certification benefits: where do we stand?. Journal of Industrial Engineering and Management. 2017;10(3):476-94.

[22] Prusak A, Kafel P, Stefanów P, Strojny J, Garcia-Melon M. The application of the AHP risk-benefit assessment in certification of organic farming. Modern Management Review. 2015;2(4): 137-59.

[23] ISO Survey of certifications to management system standards - Full results [Internet]. International Organization for Standardization.c2020 - [cited 2020 Dec 31]. Available from: https://isotc.iso.org/livelink/livelink?func=ll\&objld=18808772 \&objAction=browse \&viewType=1).

[24] Reyta F, Nugraha DN, Buana DM. The Investigation Enhancement Effect of Product Certification on Branding Toward Brand Trust. Business Journal: Jurnal Bisnis Dan Sosial. 2019 Apr 29;5(2): 57 70.

[25] Atmojo KT, Fahma F, Sutopo W. A scheme to increase Indonesian national standard certification in the batik SMEs (case study at XYZ SME). In AIP Conference Proceedings 2020 Apr 13 (Vol. 2217, No. 1, p. 030175). AIP Publishing LLC.

[26] Fauziyah SR, Fahma F, Zakaria R. An Assesment of Sebelas Maret University Readiness to Establish Product Certification Bodies (LSPro) for Bottled Drinking Water (AMDK) Products Based on SNI ISO/IEC 17065: 2012. In IOP Conference Series: Materials Science and Engineering 2019 Aug (Vol. 598, No. 1, p. 012003). IOP Publishing.

[27] Franceschini F, Galetto M, Maisano D, Mastrogiacomo L. A proposal of a new paradigm for national quality certification systems. International Journal of Quality \& Reliability Management. 2011 Apr 19;28(4):364-382.

[28] Albulescu CT, Drăghici A, Fistiş GM, Truşculescu A. Does ISO 9001 quality certification influence labor productivity in EU-27. Procedia-Social and Behavioral Sciences. 2016 Jun 7;22(6):278286.
[29] Sampaio P, Saraiva P, Rodrigues AG. ISO 9001 certification research: questions, answers and approaches. International Journal of Quality \& Reliability Management. 2009 Jan 9; 26(1):38-58.

[30] Terziovski M, Guerrero JL. ISO 9000 quality system certification and its impact on product and process innovation performance. International Journal of Production Economics. 2014 Dec 1;158:197-207. doi: 10.1016/j.ijpe.2014.08.011.

[31] Islam MM, Karim MA, Habes EM. Relationship between quality certification and financial \& non-financial performance of organizations. The Journal of Developing Areas. 2015;49(6):119-32.

[32] Tarí JJ, Molina-Azorín JF, Heras I. Benefits of the ISO 9001 and ISO 14001 standards: A literature review. Journal of Industrial Engineering and Management (JIEM). 2012;5(2):297-322. doi:10.3926/jiem.488.

[33] Kakouris AP, Sfakianaki E. Impacts of ISO 9000 on Greek SMEs business performance. International Journal of Quality \& Reliability Management. 2018 Nov 29;35(10):2248-71. https://doi.org/10.1108/IJQRM-10-2017-0204.

[34] Talapatra S, Santos G, Uddin K, Carvalho F. Main Benefits of Integrated Management Systems Through Literature Review. International Journal for Quality Research. 2019 Jun 6;13(4):1037-54.

[35] Sá JC, Vaz S, Carvalho O, Lima V, Morgado L, Fonseca L, Doiro M, Santos G. A model of integration ISO 9001 with Lean six sigma and main benefits achieved. Total Quality Management \& Business Excellence. 2020 Oct 10: 1-25.

[36] Siltori PF, Simon Rampasso I, Martins VW, Anholon R, Silva D, Souza Pinto J. Analysis of ISO 9001 certification benefits in Brazilian companies. Total Quality Management \& Business Excellence. 2020 Apr 29:1-19.

[37] International Organization for Standardization. ISO/IEC 17021:2015 - Conformity assessment - Requirements for bodies providing audit and certification of management systems. Geneva: ISO;2015.

[38] International Organization for Standardization. ISO/IEC 17065:2012 - Conformity assessment - Requirements for bodies certifying products, processes and services. Geneva: ISO;2012.

[39] International Organization for Standardization. ISO/IEC 17067:2013 - Conformity Assessment - Fundamentals of Product Certification and Guidelines for Product Certification Schemes. Geneva: ISO;2013.

[40] Fonseca LM. ISO 9001 quality management systems through the lens of organizational culture. Calitatea. 2015 Oct 1;16(148):5459.

[41] Sıtkı Ilkay M, Aslan E. The effect of the ISO 9001 quality management system on the performance of SMEs. International Journal of Quality \& Reliability Management. 2012 Jul 27;29(7):753-778. https://doi.org/10.1108/02656711211258517.

[42] Terziovski M, Power D. Increasing ISO 9000 certification benefits: a continuous improvement approach. International Journal of Quality \& Reliability Management. 2007 Feb 13;24(2):141-163. https://doi.org/10.1108/02656710710722266.

[43] Tarí JJ, Heras-Saizarbitoria I, Pereira J. Internalization of quality management in service organizations. Managing Service Quality. 2013 Nov 18;23(6):456-73. https://doi.org/10.1108/MSQ-062012-0060.

[44] Kafel P, Sikora T. Benefits of implementation and certification of management systems in the food industry enterprises. In 5th International Quality conference. 2011 May 20 (Vol. 20).

[45] Qijun J, Batt PJ. Barriers and benefits to the adoption of a thirdparty certified food safety management system in the food 
processing sector in Shanghai, China. Food Control. $2016 \mathrm{Apr}$ 1;62:89-96. doi: 10.1016/j.foodcont.2015.10.020.

[46] Păunescu C, Argatu R, Lungu M. Implementation of ISO 22000 in Romanian companies: Motivations, difficulties and key benefits. Amfiteatru Economic. 2018 Feb 1;20(47):30-45.

[47] Jewalikar AD, Shelke DA. The Main Perceived Benefits Associated with HSE Management Systems Certification in MSME Tool Rooms Post Quality Management System Certification. International Journal of Management (IJM). 2013 May;4(3):125-34.

[48] Santos G, Rebelo M, Lopes N, Alves MR, Silva R. Implementing and certifying ISO 14001 in Portugal: motives, difficulties and benefits after ISO 9001 certification. Total Quality Management \& Business Excellence. 2016 Nov 1;27(11-12):1211-23. doi:10.1080/14783363.2015.1065176.

[49] Mazzi A, Toniolo S, Mason M, Aguiari F, Scipioni A. What are the benefits and difficulties in adopting an environmental management system? The opinion of Italian organizations. Journal of Cleaner Production. 2016 Dec 15;139:873-85. doi: 10.1016/j.jclepro.2016.08.053.

[50] Wang J, Mao Y. Pains and gains of environmental management system certification for the sustainable development of manufacturing companies: Heterogeneous effects of industry peer learning. Business Strategy and the Environment. 2020 Jul;29(5):2092-109.

[51] Asmuni A, Jamil M, Rafianti F. Dynamics of Application of Halal Certification on Medicine Products in Indonesia. Budapest International Research and Critics Institute (BIRCI-Journal): Humanities and Social Sciences. 2020 Oct 27;3(4):2938-47.

[52] Muneeza A, Mustapha Z. Halal certification process for fisheries products in Maldives. Journal of Islamic Marketing. 2020 Mar 15. https://doi.org/10.1108/JIMA-02-2019-0035.

[53] Calder R. Halalization: Religious Product Certification in Secular Markets. Sociological Theory. 2020 Dec;38(4):334-61.
[54] Ratnasari RT, Gunawan S, Rusmita SA, Prasetyo A. Halal Food Certification to Improve the Competitiveness of East and Middle Business in Indonesia. KnE Social Sciences, The 2nd International Conference on Islamic Economics, Business, and Philanthropy (ICIEBP) Theme: "Sustainability and Socio-Economic Growth". 2019 Mar 31:1044-56.

[55] Potts, J. Alternative Trade Initiatives and Income Predictability: Theory and evidence from the coffee sector. Institut international du développement durable. IISD, Winnipeg, Manitoba;2007 Jul.

[56] Alič M. Impact of ISO 9001 certification cancellation on business performance: a case study in Slovenian organisations. Total Quality Management \& Business Excellence. 2014 Jun 5;25(7-8): 790-811.

[57] Burda A. The Social and Economic Importance of Standardization Ensuring Auditing and Certifying the Quality of Goods. Knowledge Horizons Economics. 2017 Oct 1;9(4):62-4.

[58] Susanto DA, Isharyadi F, Ritonga M. [Economic Benefits of Standards on Small Medium Entreprise Using ISO Methodology]. Jurnal Standardisasi. 2018;19(1):25-38. Indonesian.

[59] Dang G, Pheng LS. Theories of economic development. In Infrastructure investments in developing economies. 2015, 11-26. Springer, Singapore. doi:10.1007/978-981-287-248-7_2.

[60] Soubbotina TP. Beyond economic growth: An introduction to sustainable development. The World Bank; 2004 Jun 30.

[61] Anghelache C, Anghel MG. Econometric methods and models used in the analysis of the factorial influence of the gross domestic product growth. Network Intelligence Studies. 2017 Jan;9(1):67-78.

[62] International Accreditation Forum [Internet]. cInternational Accreditation Forum, Inc [cited 2020 Dec 31]. IAF members \& signatories: Accreditation Body Member. Available from: https://www. iaf.nu/articles/IAF_MEM_Indonesia/78. 